\title{
Mark Emmerson \\ Remedial habitat creation: does Nereis diversicolor play a confounding role in the colonisation and establishment of the pioneering saltmarsh plant, Spartina anglica?
}

Received: 15 February 1999 / Received in revised form: 4 June 1999 / Accepted: 11 June 1999

\begin{abstract}
Increasing concerns over global warming and expected sea level rises have led to the adoption of new coastal management strategies around the south-east coast of England. This paper explores the role played by the estuarine invertebrate Nereis diversicolor in limiting the colonisation and establishment of the invasive pioneering salt marsh plant, Spartina anglica. The biology of $N$. diversicolor is briefly reviewed and data from field experiments are presented demonstrating significant negative effects of worm abundance on transplanted $S$. anglica biomass. Laboratory-based experiments demonstrated significant negative effects of $N$. diversicolor abundance on the survival of $S$. anglica seeds transplanted to sediment cores. The importance of estuarine invertebrates in engineering the mudflat habitat may confound the foreseen ecosystem services and function provided by saltmarsh management schemes.
\end{abstract}

Key words Community Structure $\cdot$ Composition · Function

\section{Introduction}

The ragworm Nereis diversicolor has a wide distribution ranging from the North Sea and western Baltic, through the English Channel and the Atlantic of north-western Europe to the Mediterranean (Hayward and Ryland 1995). N. diversicolor inhabits U-shaped or ramifying burrows in the sediment and has traditionally been described as a detritus and substrate feeder on the basis of gut content analysis (Goerke 1971; Fauchald and Jumars 1979) However, anecdotal observations and laboratory experiments carried out by Pashley (1985) suggest that $N$. diversicolor is an omnivore, feeding by carrion scavenging, deposit and filter

Communicated by H. Asmus and R. Asmus

M. Emmerson (

Culterty Field Station, Department of Zoology,

University of Aberdeen, Newburgh, Ellon, AB41 8RU, UK

e-mail: m.emmerson@abdn.ac.uk feeding, and active consumption of invertebrates, including conspecifics (Harley 1956; Goerke 1971; Fauchald and Jumars 1979; Reise 1979; Pashley 1985; Riisgård 1991; Riisgård et al. 1994). The combination of locally high densities, burrowing habit and ingestion of a range of particles of widely different types has led some authors to suggest that $N$. diversicolor may have major impacts on the stability of the sediment matrix and other infaunal species (Rönn et al. 1988). In the present paper, this functional role of $N$. diversicolor is examined with respect to the establishment and growth of the high-shore, pioneer saltmarsh grass, Spartina anglica. Previous studies have reported significant seed predation by Corophium volutator on another pioneer saltmarsh species, Salicornia europaea (Gerdol and Hughes 1993). An understanding of the effects of intertidal invertebrates on these species is important if proposed management strategies to allow the development of saltmarsh communities in areas of managed retreat (Dixon et al. 1998) are to be properly evaluated

\section{Methods}

Spartina anglica is a hybrid cross resulting from the American $S$. alterniflora and the European S. maritima. On the saltmarsh it is present in the fertile tetraploid form and a sterile diploid form. The sterile hybrid is termed $S$. townsendii and the fertile hybrid $S$. anglica. Identification is complicated by the occurrence in some diploid individuals of fertile seeds.

Field studies

The Essex coast, south-east England (Fig. 1) has been accorded considerable conservation status; it is considered to be one of the top five coastal wetlands in Britain in terms of value to bird, invertebrate and plant communities and is now one of 22 areas in England designated by the Ministry of Agriculture, Fisheries and Food (MAFF) under the Environmentally Sensitive Areas (ESA) scheme. The ESA is largely within the greater Thames Estuary Natural Area, designated as part of the UK Biodiversity Action Plan and a significant proportion is included within the mid-Essex Special Protection Area (SPA) in addition to being classified as a RAMSAR site, under the Convention on Wetlands of International Importance signed at Ramsar, Iran, in 1971. The adjoining mud- 
Fig. 1 Essex coastline showing location of study site Hamford Water, and the extent of enwalled saltmarsh in Essex, with potential flood zones
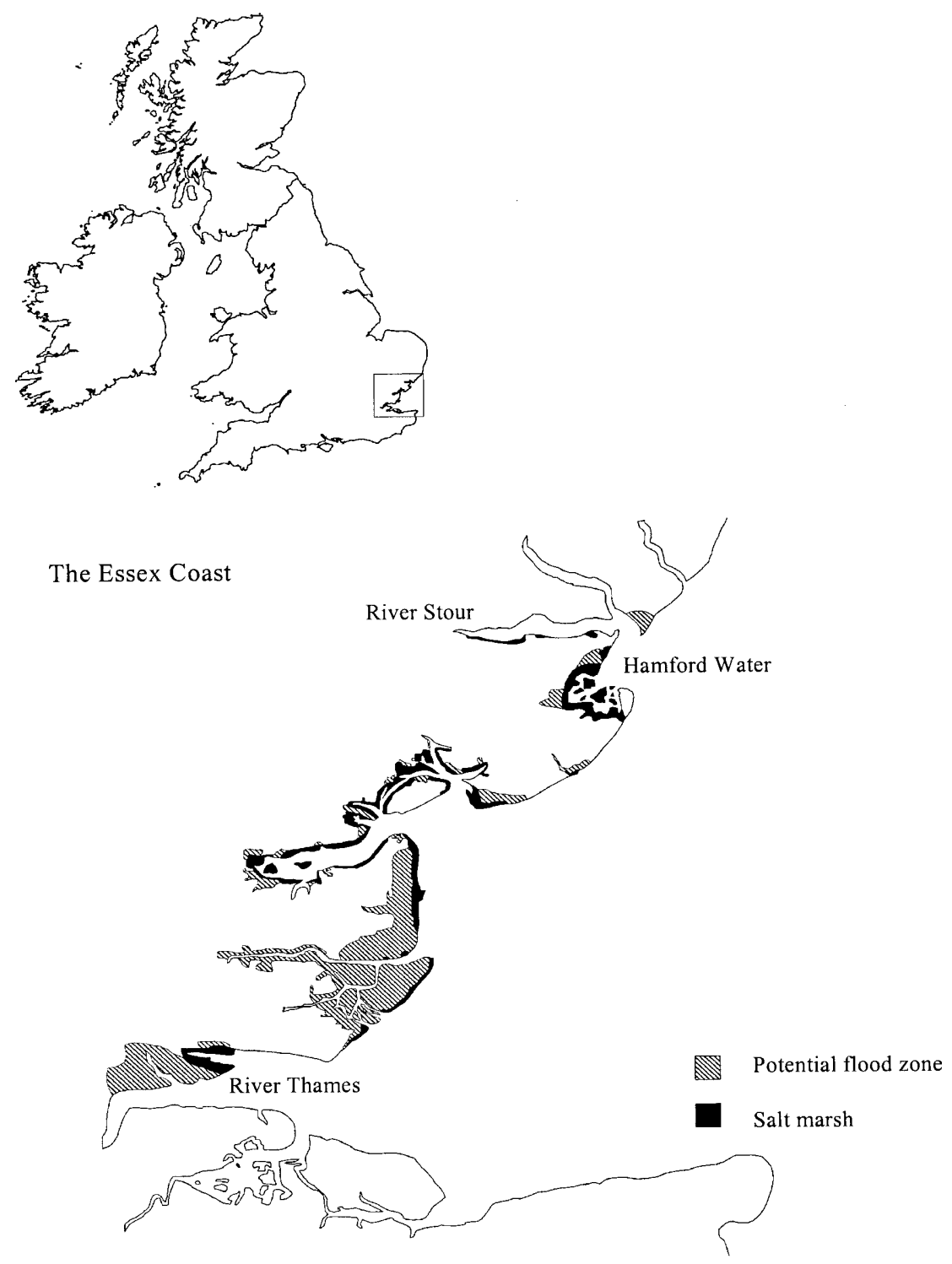

flats, saltmarshes and estuaries are a proposed marine Special Area of Conservation (SAC) (MAFF 1998).

The field work was carried out in a region of Hamford Water known as the "wade" ( $1^{\circ} 10^{\prime} 60^{\prime \prime}$ E 51 $1^{\circ} 50$ '15" N). Hamford Water, found south of the river Stour estuary (Fig. 1) is an internationally important site for many migratory birds, such as brent geese (Brenta bernicla), redshank (Tringla totanus), wigeon (Anas penelope), oyster catchers (Haematopus ostralegus) and shelduck (Tadorna tadorna).

Boating activity in the western reaches of the estuary is limited by the presence of a causeway which runs across the mudflats to Horsey Island and which has been present historically since the seventeenth century. Located behind the seawall and formed when coastal defences were created is a "borrow dike". This runs the length of the coastal defences at Hamford Water and at various points along the seawall is connected to the saltings on the seaward side by drains. This provides a source of fresh water to the marsh over most periods of the year. Beyond the "borrow dike", the land use is dominated by agriculture and pasture.

\section{Spartina transplant experiments}

To assess the effects of $N$. diversicolor on the abundance and distribution of $S$. anglica, six replicate $N$. diversicolor exclusion arsituated approximately $60 \mathrm{~m}$ along and adjacent to the causeway to Horsey Island, at a site noted to have a particularly high abundance of $N$. diversicolor (approximately 950-1,000 $\mathrm{m}^{-2}$ ). Because of the deep burrowing nature of $N$. diversicolor, the worms could not be removed without sieving and disrupting the sediment structure. To overcome this problem, a turf of mud $30 \times 30 \mathrm{~cm}$ and 5 $7 \mathrm{~cm}$ thick was removed, a mat of netting $500 \mu \mathrm{m}$ mesh size was inserted beneath the mud and the turf returned to its original position. The surface of the exclusion site was then sprayed with a proprietary pyrethrum-based insecticide (Bug Gun, ICI) to remove any worms that remained. This procedure was repeated once, after 2 weeks. Each exclusion area had an appropriate control area located approximately $50 \mathrm{~cm}$ away. These control areas underwent the same treatment as exclusion areas but without insertion of the excluding mat and application of the pesticide to remove worms.

Specimens of $S$. anglica were collected, individually rinsed and wet weights recorded using an Aculab A639 J portable balance. Each plant was individually labelled using a piece of plastic and a small length of wire. Five plants were placed in each exclusion and control area and left for 28 days. Upon collection, plants were rinsed in seawater and taken to the laboratory where they were fixed in formalin.

Three cores $(6.5 \mathrm{~cm}$ diameter) were taken from each exclusion and control area; these were returned to the laboratory and sieved eas were established in October 1994. The exclusion areas were 
using a sieve of mesh size $500 \mu \mathrm{m}$. Any $N$. diversicolor found were counted and stored live for later use in laboratory experiments. The maximum root and shoot lengths were measured and wet weights recorded. The plants were then dried to a constant weight at $60^{\circ} \mathrm{C}$. The roots were then separated from shoots and rhizomes and weighed separately.

\section{Laboratory studies}

These experiments were carried out to determine any effect $N$. diversicolor might be having on the colonisation of mud-flats by $S$. anglica through seed propagation.

\section{Seed transplants to tidal simulation}

In January 1995, 20 corers, $10 \mathrm{~cm}$ diameter and $11 \mathrm{~cm}$ long, were used to collect cores of sediment from a site at the "wade", Hamford Water, Essex, UK. The cores of sediment were taken to the laboratory and stored until used in an artificial tidal regime of $3 \mathrm{~h}$ submergence every $12 \mathrm{~h}$, using water $34.5 \pm 1.54$ (psu) at $10^{\circ} \mathrm{C}$ and in $12 \mathrm{~h}$ light/ $12 \mathrm{~h}$ dark. Exclusion cores had $N$. diversicolor excluded from the surface by placing a circular disc of netting $(500 \mu \mathrm{m}$ mesh size) within the sediment at a depth of $2 \mathrm{~cm}$. Control cores had seven $N$. diversicolor added to each (equivalent to $900 \mathrm{~m}^{2}$ ).

S. anglica seeds were collected in late October 1994. The seed heads were collected from the plants and returned to the laboratory, where seeds were removed. All seeds were washed in a 5\% solution of sodium hypochlorite after Marks and Truscott (1974) and then rinsed in distilled water and stored in petri dishes with dampened discs of filter paper at $10^{\circ} \mathrm{C}$ for later use.

\section{S. anglica seed transplant experiment 1}

Dehusked seeds of $S$. anglica were germinated at $26^{\circ} \mathrm{C}$ after being pierced with a needle and exposed to $24 \mathrm{~h}$ light. These were then transplanted to the tidal system. Ten S. anglica seeds were transplanted to each of five exclusion and five control cores. These were left in the tidal simulation for 14 days. At the end of this period those seeds which were recoverable from the sediment surface were counted. Many of the seeds were not immediately recoverable due in part to their small size and the bioturbatory activities of $N$. diversicolor in control cores. To determine to what extent the seeds had been grazed (eaten) or buried, each core was sectioned in $0.5 \mathrm{~cm}$ slices to a depth of $3 \mathrm{~cm}$ in control cores and to the depth of the netting in exclusion cores. Each section was sieved using a sieve of mesh size $500 \mu \mathrm{m}$ and the depth at which seeds were found in the sediment column were noted. The remaining sediment was sieved (mesh size $500 \mu \mathrm{m}$ ) to determine the number of individual worms in each core.

\section{S. anglica seed transplant experiment 2}

Dehusked intact seeds were treated with gibberellic acid. This initiated abnormal levels of growth in the seeds relative to untreated seeds. These oversized precocious seedlings were transplanted to five control and five exclusion mud cores to allow for easy recovery and quantification of worm-caused damage. Five seeds were placed in each core. These were left in the tidal simulation for a period of 14 days at the end of which time the procedures detailed in transplant experiment 1 for the recovery and quantification of seeds were repeated.

\section{Results}

\section{Spartina transplant experiments}

There were significantly more worms in control areas $(P<0.05$, unpaired $t$-test; Fig. 2$)$. Weight loss in $S$. ang-

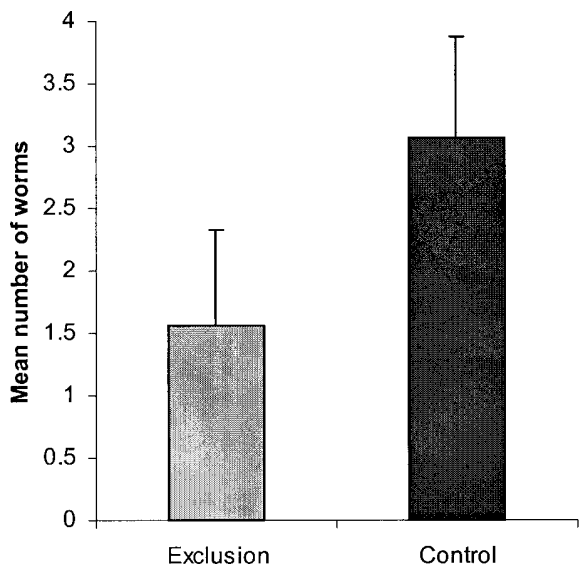

Fig. 2 Field experiments: there were significantly more worms in control areas compared to the treatment sites $(P<0.05$, unpaired $t$ test)

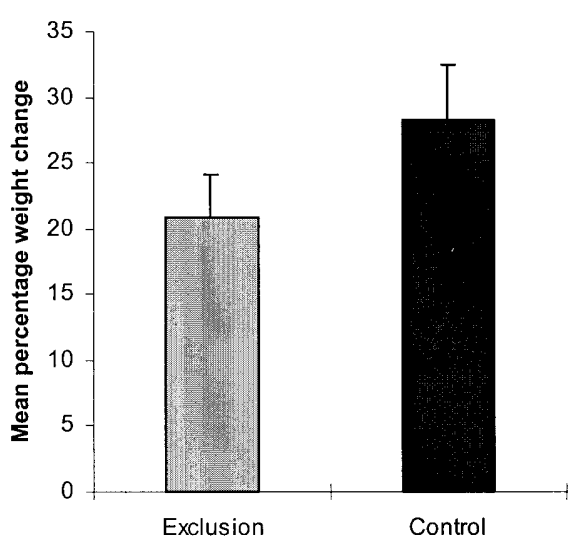

Fig. 3 Field experiments: mean percentage change in weight over duration of experiment was significantly different $(P<0.007$, unpaired $t$-test)

lica plants from both $N$. diversicolor exclusion and control areas was significant over the duration of the experiment $(P<0.000$ and $P<0.000$, respectively, paired $t$-test). The mean percentage change in weight of $S$. anglica from control areas containing $N$. diversicolor was significantly greater (Fig. 3) than in those specimens of $S$. anglica transplanted to sites in which $N$. diversicolor had been excluded $(P<0.007$, unpaired $t$-test). There was no significant difference between the mean maximum shoot length of $S$. anglica from control and $N$. diversicolor exclusion areas (Fig. 4). However, the roots of S. anglica plants transplanted to control areas and exposed to significantly higher densities of $N$. diversicolor $(P<0.05$, unpaired $t$-test; Fig. 2), were significantly shorter (Fig. 4) than the roots of plants transplanted to $N$. diversicolor exclusion areas $(P<0.02$, unpaired $t$-test $)$. There was a significant difference (Fig. 5) between the mean dry weight fraction of stems/rhizomes and roots from control and $N$. diversicolor excluded areas $(P<0.01$, unpaired $t$ test and $P<0.05$, unpaired $t$-test, respectively). 


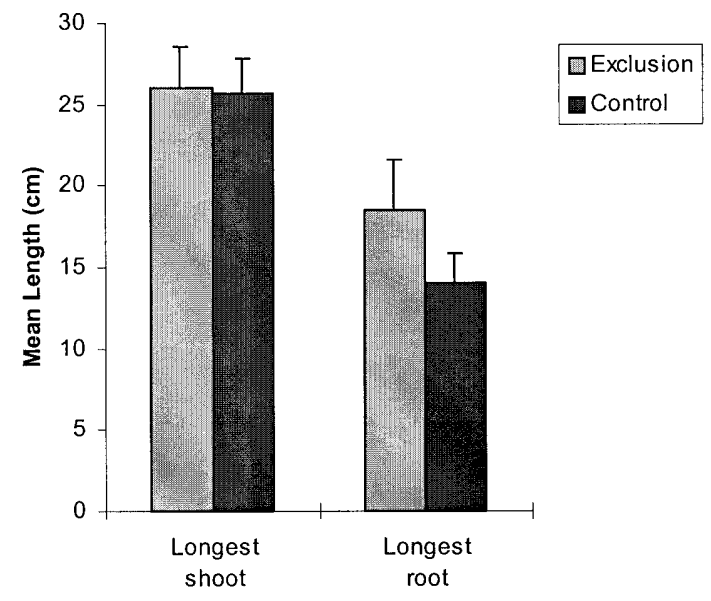

Fig. 4 Field experiments: mean longest shoot lengths of $S$. anglica were not significantly different, but the mean longest root lengths of plants exposed to $N$. diversicolor were significantly shorter $(P<0.05$, unpaired $t$-test $)$

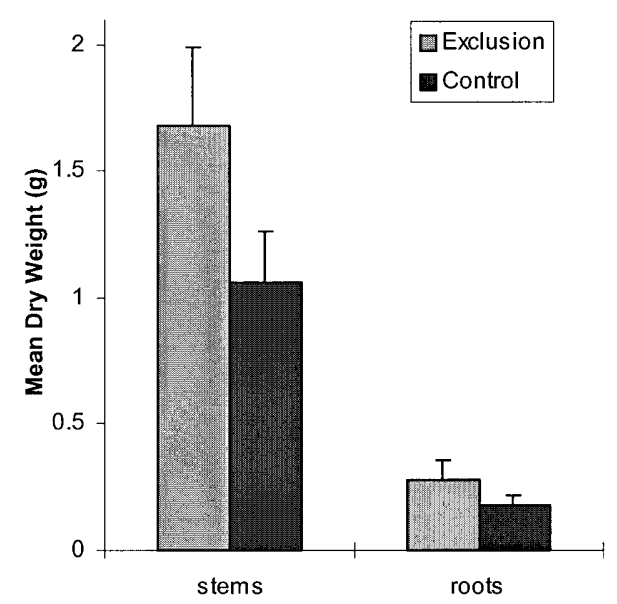

Fig. 5 Field experiments: S. anglica from control areas weighed significantly less than $S$. anglica plants that had not been exposed to $N$. diversicolor, for both the stem/rhizome and root fractions $(P<0.01$ and $P<0.05$, respectively, unpaired $t$-test)

\section{Laboratory studies}

\section{S. anglica seed transplant experiment 1}

The depth distribution of seeds from control and exclusion cores were significantly different $\left(P<0.01, \chi^{2}\right)$. More seeds were found on the sediment surface $(0 \mathrm{~cm})$ in $N$. diversicolor-excluded mud cores than in control cores and more seeds were found at depth in cores containing $N$. diversicolor (Fig. 6a).

\section{S. anglica seed transplant experiment 2}

The depth distribution of seeds from control and exclusion cores were not significantly different when compared using $\chi^{2}$. However, the mean number of seeds

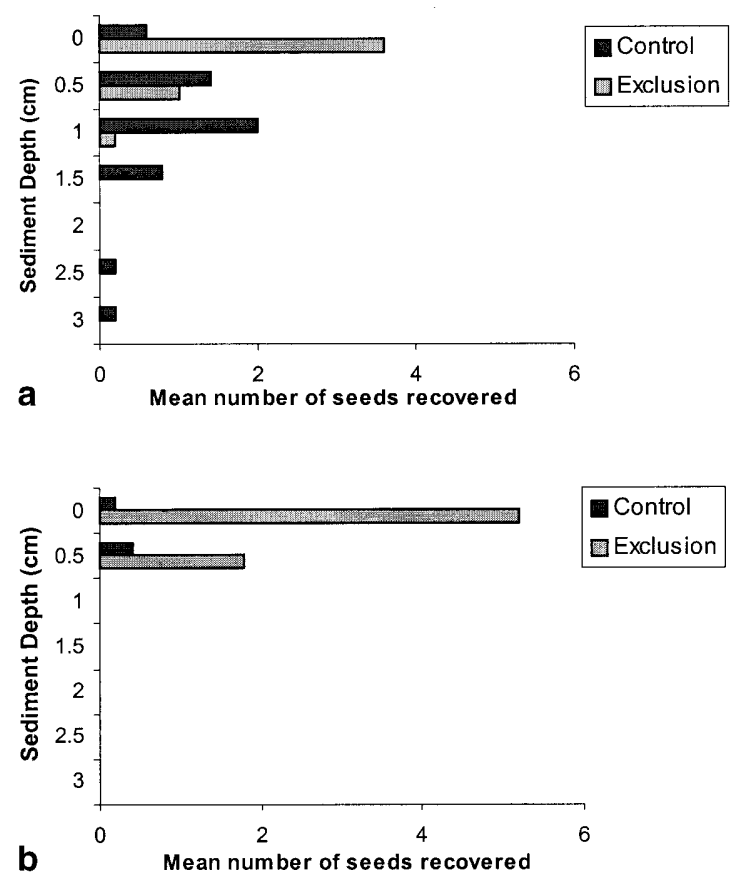

Fig. 6a,b Laboratory experiments. a Seed transplant experiment 1: the depth at which $S$. anglica seeds were recovered from the sediment was significantly different $\left(P<0.01, \chi^{2}\right)$, fewer seeds were recovered from cores containing $N$. diversicolor. b Seed transplant experiment 2: the depth distribution of seeds recovered from control and $N$. diversicolor treatment cores was not significantly different, but mean number of seeds on sediment surface differed significantly $(P<0.006$, unpaired $t$-test $)$

found at the sediment surface $(0 \mathrm{~cm})$ was significantly different in control and exclusion cores $(P<0.006$, unpaired $t$-test), with more seeds present at the surface in cores from which $N$. diversicolor had been effectively removed (Fig. 6b).

\section{Discussion}

Field studies

The significant loss in weight of $S$. anglica from both control and exclusion areas can be accounted for by the autumn senescence of $S$. anglica leaves, also reported for S. alterniflora by Levinton and Stewart (1988). This can in turn be correlated with seasonal increases in sediment microbial productivity (Rublee 1982), ultimately benefiting deposit-feeding communities. In the presence of $N$. diversicolor, $S$. anglica plants lost a significantly higher proportion of their weight over the course of the experiment compared with plants in plots from which $N$. diversicolor had been excluded. Specimens of S. anglica from control plots containing $N$. diversicolor had significantly shorter mean maximum root lengths than specimens from plots, again, from which $N$. diversicolor had been removed. The reduced mean maximum root lengths of $S$. anglica when exposed to $N$. diversicolor might infer some form of grazing pressure on S. anglica, although 
none has been previously reported. If grazing were to have occurred, it may have been an active process (the worms actively sought the roots) or a passive process (the worms unselectively grazed everything in the vicinity of their burrows). Worms forage for a short distance immediately around their burrows, extending short distances (typically $1.5 \mathrm{~cm}$ ) in a straight line, whilst taking bites from the sediment surface with their jaws and proboscis, the jaws being used as rakes to aid the collection of surface material by the everted proboscis (Goerke 1971). This second conclusion is more likely, given Pashley's (1985) conclusions regarding the unselective feeding nature of $N$. diversicolor. Alternatively, the physical burrowing activities of $N$. diversicolor might in some way impair root growth if in close proximity to $S$. anglica. $N$. diversicolor inhabits U-shaped or ramifying burrows in the sediment, most burrows typically being approximately $10 \mathrm{~cm}$ deep (Harley 1956), although deeper burrows have been described, to a depth of $30 \mathrm{~cm}$ in summer (Schäfer 1972) and up to $60 \mathrm{~cm}$ in winter (Muus 1967; cited in Pashley 1985). The mean root length of plants from $N$. diversicolor-exclusion areas were significantly longer than in control plants despite the presence of an excluding mat at a depth of 5-7 cm in the sediment. It was noted whilst collecting plants from each area that the roots of $S$. anglica had in fact penetrated the excluding mesh to a depth of $10-15 \mathrm{~cm}$ in some instances.

\section{Laboratory studies}

These experiments have demonstrated the overall trend of the loss and disappearance of seeds from control mud cores containing high densities of $N$. diversicolor equal to $900 \mathrm{~m}^{-2}$. Jensen (1992) reported densities ranging from 2,000 to 3,800 individuals $\mathrm{m}^{-2}$ in the Skallingen area of the Danish Wadden sea, whilst Riisgård (1991) reports densities of 2,400 individuals $\mathrm{m}^{-2}$ from Odense Fjord, Denmark, a 2- to 4-fold increase in the densities used in these experiments. It is assumed that those worms present grazed any seeds that were not recovered. This "grazing" is most likely a passive process, involving shredding of $S$. anglica seeds into smaller unrecognisable fragments, which subsequently form the basis for detritus as they are progressively decomposed by bacteria. Groenendijk (1986) described the loss of transplanted seeds from sediments, through erosion/accretion processes and the rapid deterioration of implanted seeds in the sediment, which caused a serious reduction in potential population size. The combined bioturbatory effects of $N$. diversicolor and $C$. volutator, being dominant members of the deposit-feeding community, could also conceivably account for such losses. This is a factor which at the time may have been overlooked.

In south-east England the development of historical coastal defences has contributed to a reduction in the area of intertidal habitats by fixing the limit of their landward migration; this effect is often referred to as "coastal squeeze" (MAFF 1995). This has led to the adoption of some novel management strategies at a number of localities around the Essex coast. These schemes known variously as "coastal realignment" and "managed retreat" strategies have involved removal or breaching, of certain existing, but deteriorated, seawalls and make use of enhanced low level counterwalls to limit the extent of saline flooding. The philosophy behind this approach has been "to allow natural processes to work, with as little human engineering and interference as possible" (Dixon et al. 1998).

British and other Northern European saltmarshes are found in the region above the lowest neap high tide. Within this region, saltmarsh plants are not covered by the tide daily but are covered periodically by spring high tides. Saltmarshes demonstrate a clear zonation and successional sequence from low to high elevations (McLusky 1989). Much attention has been given to the relationship between saltmarsh development and factors such as length of the tidal immersion (Ranwell et al. 1964) wave action at the seaward edge (Morley 1973) and erosion/accretion processes limiting the distribution and viability of seeds and seedlings (van Eerdt 1985; Groenendijk 1986). The relationship between saltmarsh development and benthic deposit-feeding macrofaunal communities has largely been ignored. Gerdol and Hughes (1993) demonstrated significant negative effects of the amphipod Corophium volutator (a prominent member of mudflat communities occurring at densities of up to $140,000 \mathrm{~m}^{2}$ ) on the colonisation of mud by $S$. europaea and postulated that the bioturbatory feeding habit of $C$. volutator might be responsible for the loss and lower limit of pioneer zone vegetation. The plants most typical of this pioneer zone are Salicornia europaea and the invasive $S$. anglica.

Seed setting and the resulting germination is not the main form of propagation in seagrasses and cord grasses, but vegetative expansion is (Kenworthy and Fonseca 1977; Groenendijk 1986; Hartman 1988; Goubin and Loqués 1991). If this is the case then the results of the experiments detailed here imply that $S$. anglica's vegetative and propagative expansion may be slowed or halted by $N$. diversicolor in areas where both are common. Gerdol and Hughes (1993) demonstrated that Salicornia europaea seedlings were able to survive beyond the pioneering zone when the bioturbatory effects of the amphipod $C$. volutator were removed.

Seaward of the pioneering zone, mudflats in the UK were formerly dominated by the seagrass Zostera marina with its associated infauna. These beds of $Z$. marina along with those on most of the North Sea coast of north-western Europe, were decimated during the Z. marina "wasting disease" epidemic of the early 1930s. In the absence of $Z$. marina, benthic communities of deposit-feeding invertebrates dominate the mudflat. Deposit feeders can be strong habitat fabric interactors, altering the structural nature of marine soft sediments (Nowell et al. 1981). Levinton (1995) argues that strongly interacting species may affect an ecosystem through two distinct 
routes. Firstly, species might be biological interactors and affect other species by being predators, grazers or competitors. Within some marine ecosystems, predators may often exert strong effects on prey species (Paine 1966, 1974; Harrold and Reed 1985) to the point where the ecosystem is directed into distinct and stable states. In marine and estuarine soft sediment systems, these interactions have been well documented and in most cases there is no difficulty in categorising them, e.g. predation (Commito 1982; Highsmith 1982; Peterson 1982; Ambrose 1984; Smith et al. 1996), competition (Peterson and Andre 1980; Levin 1982; Race 1982; Wilson 1983; Flach 1992; Flach and De Bruin 1994). The presence of both predators and competitors can have important consequences for the relative abundance of different plant and animal species and hence community structure. Secondly, Levinton (1995) argues that species may be habitat fabric interactors, altering and engineering the physical habitat itself. The burrowing and feeding activity of deposit-feeding infaunal marine invertebrates alters the fabric of the sediment, which in turn alters the environment for the deposit feeder, and other constituents of the infaunal community. In this sense deposit feeders are therefore engineers, sensu Lawton and Jones (1995) and Jones et al. (1994) and affect the habitat fabric of the ecosystem (Levinton 1995).

Evidence exists to suggest an increase (doubling) in $N$. diversicolor abundance in the Wadden Sea area (Beukema 1989; Reise et al. 1989; Jensen 1992) which was accompanied there by increased algal blooms on the mudflats. These have similarly doubled their primary production and biomass in localised areas. This is mainly related to increased eutrophication. Similar algal mat blooms have been experienced along the east coast of Great Britain (Raffaelli 2000) and may have been accompanied there by similar increases in $N$. diversicolor abundance. No historical data are available for the site at Hamford Water in the present study, but it is tentatively suggested that increases in $N$. diversicolor abundance around the south-east coast of England and those countries bordering the southern North Sea are not unlikely.

The suggestion by Dixon et al. (1998) that "managed retreat" or "coastal realignment" schemes represent a minimalist approach and provide a cost-effective solution to the problem of seawall maintenance through a process of sustainable natural development that ensures evolution towards a natural system, may well be true. However, evidence from the present study detailing the effects of $N$. diversicolor on S. anglica, and other studies (Gerdol and Hughes 1993) detailing the negative effects of $C$. volutator on Salicornia europaea distribution, contribute to a growing body of evidence that indicates the importance of bioturbating infaunal invertebrates in limiting the distribution of pioneering saltmarsh plants and hence saltmarsh development. Levinton (1995) argues that deposit feeders occupy space within, and may monopolise the environment, thus excluding other species. Often single species regulate the composition of sediment community assemblages both by modifying sediment chemistry and physical structure, and by displacing other species. Regarding this, it is not clear whether other species might refer to plants or animals; both could potentially compete for the same resourcespace within the sediment. Dixon et al. (1998) report some preliminary results as being earlier than expected colonisation by halophytic plants and rapid take-up by marine invertebrates. Marine bioturbators are major controllers of sediment ecosystems, their impact on human attempts at ecosystem engineering and manipulations of the "natural environment" towards some desired end state should be considered carefully.

In conclusion, coastal realignment schemes could develop into desired areas of new saltmarsh habitat serving the purpose for which they were conceived (economic coastal defence). It is also tentatively suggested that coastal realignment schemes could simply develop into new areas of mud-flat dominated by infaunal communities, with major detrimental impacts on the desired ecosystem service that these newly created habitats were perceived to serve. Although the present study concentrates on $N$. diversicolor it contributes to the growing body of evidence indicating the importance of bioturbating infaunal invertebrates in regulating mud-flat community structure. It is apparent that the effects of infaunal invertebrates on pioneering saltmarsh plants are worthy of further investigation, if the UK government is to pursue an extensive policy of "coastal realignment" or "managed retreat" in the face of economic concerns over global sea level rise.

Acknowledgements Many thanks to Dr. R.G. Hughes for his supervision and comments whilst this work was carried out. Thanks also to Dr. D. Raffaelli, R. Leaper and Dr. J. Yearsley for valuable comments on the manuscript, and to $\mathrm{S}$. Way for time spent on figures.

\section{References}

Ambrose WG Jr (1984) Influences of predatory polychaetes and epibenthic predators on the structure of a soft-bottom community in a Maine estuary. J Exp Mar Biol Ecol 81:115-145

Beukema JJ (1989) Long-term changes in the macrozoobenthic abundance on the tidal flats of the Western part of the Dutch Wadden Sea. Helgol Wiss Meeresunters 43:405-415

Commito JA (1982) Importance of predation by infaunal polychaetes in controlling the structure of a soft-bottom community in Maine, USA. Mar Biol 68:77-81

Dixon AM, Leggett DJ, Weight RC (1998) Habitat creation opportunities for landward coastal re-alignment: Essex case studies. J Chart Inst Water Environ Manage 12:107-112

Eerdt MM van (1985) The influence of vegetation on erosion and accretion in saltmarshes of the Oosterschelde, the Netherlands. Vegetatio 62:367-373

Fauchald K, Jumars P (1979) The diet of worms: a study of polychaete feeding guilds. Oceanogr Mar Biol Ann Rev 17:193284

Flach EC (1992) The influence of four macrozoobenthic species on the abundance of the amphipod Corophium volutator on the tidal flats of the Wadden Sea. Neth J Sea Res 29:379-394

Flach EC, De Bruin W (1994) Does the activity of cockles, Cerastoderma edule (L.) and lugworms, Arenicola marina L., make Corophium volutator Pallas more vulnerable to epibenthic predators: a case of interaction modification? J Exp Mar Biol Ecol 182:265-285 
Gerdol V, Hughes RG (1993) Effect of the amphipod Corophium volutator on the colonisation of mud by the halophyte Salicornia europaea. Mar Ecol Prog Ser 97:61-69

Goerke H (1971) Die Ernahrungsweise der Nereis-Arten (Polychaeta, Nereidae) der deutschen Kusten. Veroeff Inst Meeresforsch Bremerh 13:1-50

Goubin C, Loqués F (1991) Germinating Zostera noltii (Hornemann) found in the Etang de Diana, Corsica. Aquat Bot 42:75-79

Groenendijk AM (1986) Establishment of a Spartina anglica population on a tidal mudflat: a field experiment. J Environ Manage 22:1-12

Harley MB (1956) The feeding habits of Nereis diversicolor and related polychaetes. $\mathrm{PhD}$ thesis, University of London

Harrold C, Reed DC (1985) Food availability, sea urchin grazing, and Kelp forest community structure. Ecology 66:1160-1169

Hartman JM (1988) Recolonisation of small disturbance patches in a New England saltmarsh. Am J Bot 75:1625-1631

Hayward PJ, Ryland JS (1995) Handbook of the marine fauna of north-west Europe. Oxford University Press, Oxford

Highsmith RC (1982) Induced settlement and metamorphosis of sand dollar (Dendraster excentricus) larvae in predator-free sites: adult sand dollar beds. Ecology 63:329-337

Jensen T (1992) Macrozoobenthos on an intertidal mudflat in the Danish Wadden Sea: Comparisons of surveys made in the 1930's 1940's and 1980's. Helgol Wiss Meeresunters 46:363376

Jones CG, Lawton JH, Shachak M (1994) Organisms as ecosystem engineers. Oikos 69:373-386

Kenworthy JW, Fonseca MS (1977) Reciprocal transplant of the grass Zostera marina L. effect of substrate on growth. Aquaculture 12:197-213

Lawton JH, Jones CG (1995) Linking species and ecosystems: organisms as ecosystem engineers. In: Jones CG, Lawton JH (eds) Linking species and ecosystems. Chapman and Hall, London, pp 141-150

Levin LA (1982) Interference interactions among tube-dwelling polychaetes in a dense infaunal assemblage. J Exp Mar Biol Ecol 65:107-119

Levinton J (1995) Bioturbators as ecosystem engineers: control of the sediment fabric, inter-individual interactions, and material fluxes. In: Jones CG, Lawton JH (eds) Linking species and ecosystems. Chapman and Hall, London, pp 29-36

Levinton JS, Stewart S (1988) Effects of sediment organics, detrital input, and temperature on demography, production, and body size of a deposit feeder. Mar Ecol Prog Ser 49:259266

MAFF (1995) Shoreline management plans: a guide for coastal defence authorities. pp 1-24

MAFF (1998) Proposals for the future of the Essex Coast environmentally sensitive area, a consultation document. pp 1-42

Marks TC, Truscott AJ (1974) Variation in seed production and germination of Spartina anglica within a zoned saltmarsh. J Ecol 73:695-705

McLusky DS (1989) The estuarine ecosystem. Chapman and Hall, New York
Morley JV (1973) Tidal immersion of Spartina marsh at Bridgewater bay, Somerset. J Ecol 361:383-386

Muus BJ (1967) The fauna of Danish estuaries and lagoons. Distribution and ecology of dominant of the dominant species in the shallow reaches of the mesohaline zone. Medd Komm Dan Fisk Havunders 5:1-316

Nowell ARM, Jumars PA, Eckman JE (1981) Effects of biological activity on the entrainment of marine sediments. Mar Geol 42:133-153

Paine RT (1966) Food web complexity and species diversity. Am Nat 100:65-75

Paine RT (1974) Intertidal community structure. Experimental studies on the relationship between a dominant competitor and its principal predator. Oecologia 15:93-120

Pashley HE (1985) Feeding and optimization - the foraging behaviour of Nereis diversicolor (polychaeta). PhD thesis, University of Cambridge

Peterson CH (1982) The importance of predation and intra- and interspecific competition in the population biology of two infaunal suspension-feeding bivalves, Protothaca staminea and Chione undatella. Ecol Monogr 52:437-475

Peterson CH Andre SV (1980) An experimental analysis of interspecific competition among marine filter feeders in a softsediment environment. Ecology 61:129-139

Race MS (1982) Competitive displacement and predation between introduced and native mud snails. Oecologia 54:337-347

Raffaelli DG (2000) Interactions between macro-algal mats and invertebrates in the Ythan estuary, Aberdeenshire, Scotland. Helgol Mar Res 54:71-79

Ranwell DS, Bird ECF, Hubbard JCE, Stebbings RE (1964) Spartina marshes in southern England. V. Tidal submergence and chlorinity in Poole harbour. J Ecol 52:6627-6641

Reise K (1979) Spatial configurations generated by motile benthic polychaetes. Helgol Wiss Meersesunters 32:55-72

Reise K, Herre E, Sturm M (1989) Historical changes in the benthos of the Wadden Sea around the Island of Sylt in the North Sea. Helgol Wiss Meersesunters 43:417-433

Riisgård HU (1991) Suspension feeding in the polychaete Nereis diversicolor. Mar Ecol Prog Soc 70:29-37

Riisgård HU, Vedel A, Boye H, Larsen PS (1994) Filter-net structure and pumping activity in the polychaete Nereis diversicolor: effects of temperature and pump-modelling. Mar Ecol Prog Soc 83:79-89

Rönn C, Bronsdorff E, Nelson WG (1988) Predation as a mechanism of interference within infauna in shallow brackish water soft bottoms; experiments with an infauna predator, Nereis diversicolor O.F. Müller. J Exp Mar Biol Ecol 116:143-157

Rublee PA (1982) Seasonal distribution of bacteria in salt marsh sediments in North Carolina. Estuar Coast Shelf Sci 15:67-74

Schäfer W (1972) Ecology and palaeoecology of marine environments. Oliver \& Boyd, Edinburgh

Smith D, Hughes RG, Cox EJ (1996) Predation of epipelic diatoms by the amphipod Corophium volutator and the polychaete Nereis diversicolor. Mar Ecol Prog Ser 145:53-61

Wilson WH Jr (1983) The role of density dependence in a marine infaunal community. Ecology 64:295-306 